NBER WORKING PAPER SERIES

\author{
EMERGENCE OF ASIA: \\ REFORMS, CORPORATE SAVINGS, AND GLOBAL IMBALANCES
}

\author{
Jingting Fan \\ Sebnem Kalemli-Ozcan \\ Working Paper 22334 \\ http://www.nber.org/papers/w22334 \\ NATIONAL BUREAU OF ECONOMIC RESEARCH \\ 1050 Massachusetts Avenue \\ Cambridge, MA 02138 \\ June 2016
}

This paper was prepared for the IMF Economic Review-Bank of Korea Conference 2013. We thank the editor Pierre-Olivier Gourinchas, two anonymous referees, our discussant Markus Bruckner, and the conference participants for their comments. We also thank Alberto Martin for helpful discussions. The views expressed herein are those of the authors and do not necessarily reflect the views of the National Bureau of Economic Research.

NBER working papers are circulated for discussion and comment purposes. They have not been peer-reviewed or been subject to the review by the NBER Board of Directors that accompanies official NBER publications.

(C) 2016 by Jingting Fan and Sebnem Kalemli-Ozcan. All rights reserved. Short sections of text, not to exceed two paragraphs, may be quoted without explicit permission provided that full credit, including $\odot$ notice, is given to the source. 
Emergence of Asia: Reforms, Corporate Savings, and Global Imbalances

Jingting Fan and Sebnem Kalemli-Ozcan

NBER Working Paper No. 22334

June 2016

JEL No. E0,F0

\begin{abstract}
$\underline{\text { ABSTRACT }}$
One of the explanations for global imbalances is the self-financing behavior of credit-constrained firms in rapidly growing emerging markets. We use an extensive firm-level data set from several Asian countries during 2002-2011, and test the micro foundation of this theory by estimating the effect of an exogenous change in credit constraints, resulting from financial reforms, on firms' saving behavior. As predicted, after financial reforms, firms who were credit-constrained previously decreased their savings more (or increased their savings less) relative to unconstrained firms. However, this firm-level effect did not lead to a decrease in aggregate corporate savings as conjectured by the theory. Our sector level regressions show that corporate savings increased after financial reforms, and more so for sectors more dependent on external finance. The current account surpluses also did not register a significant deterioration after financial reforms, consistent with our findings on sectoral and aggregate corporate savings
\end{abstract}

Jingting Fan

Department of Economics

University of Maryland

fan@econ.umd.edu

Sebnem Kalemli-Ozcan

Department of Economics

University of Maryland

Tydings Hall 4118D

College Park, MD 20742-7211

and CEPR

and also NBER

kalemli@econ.umd.edu 


\title{
Emergence of Asia: Reforms, Corporate Savings, and Global Imbalances
}

\author{
Jingting Fan and Şebnem Kalemli-Özcan \\ University of Maryland and University of Maryland, CEPR, and NBER
}

\begin{abstract}
One of the explanations for global imbalances is the self-financing behavior of credit-constrained firms in rapidly g rowing emerging $m$ arkets. We use an extensive firm-level data set from several A sian countries during 2002-2011, and test the micro foundation of this theory by estimating the effect of an exogenous change in credit constraints, resulting from financial reforms, on firms' saving be havior. As predicted, after financial reforms, firms who were credit-constrained previously decreased their savings more (or increased their savings less) relative to unconstrained firms. However, this firm-level effect did not lead to a decrease in aggregate corporate savings as conjectured by the theory. Our sector level regressions show that corporate savings increased after financial reforms, and more so for sectors more dependent on external finance. The current account surpluses also did not register a significant deterioration after financial reforms, consistent with our findings on sectoral and aggregate corporate savings.
\end{abstract}

JEL Classification: E22, F41, D24, O16, O47

\section{Introduction}

Before the global financial crisis, many have argued that one of the key reasons behind the global imbalances was the high saving rates in Asian countries. The reasons behind these high savings rates are not well understood given the lack of empirical evidence on the issue.

While several theoretical papers argue that financial constraints are responsible for the increase in private savings and capital outflows (see, for example, Buera and Shin, 2009; 
Song, Storesletten, and Zilibotti, 2011), there are also other explanations. Some papers emphasize the importance of public savings, due to limited commitment of governments to pay their debt, combined with expropriation risk, in explaining the observed patterns in capital outflows from Asia (see, for example, Aguiar and Amador, 2011; Benigno and Fornaro, 2012). Mendoza, Quadrini, and Ríos-Rull (2009), on the other hand, argues that the high savings might be due to precautionary reasons and they find their way into the developed world since savers in emerging economies seek insurance in safe U.S. bonds given the limited supply of safe assets elsewhere. A similar argument is in Caballero, Farhi, and Gourinchas (2008), according to which there are not enough investment opportunities in saver countries, causing capital to flow out. ${ }^{1}$ Dooley, Folkerts-Landau, and Garber (2007) proposes an alternative theory where governments in the emerging countries of Asia influence international financial transactions, targeting current account so as to foster employment and export-led growth.

Empirical evidence so far is inconclusive. First, most of the evidence that is put forth in favor of a given model is mainly based on trends in macro data disregarding micro-level heterogeneity. Ignoring micro-level heterogeneity in the data is in sharp contrast to what these models aim to do since firm- or sector-level heterogeneity is a key micro foundation in many. Second, the few papers that do take micro-level heterogeneity seriously and undertake systematic empirical exercise with firm- or industry-level data, do so in a static environment. This means that these papers identify purely from long run average relationships between firms and/or sectors, not from dynamic firm- and/or sector-level changes in the data. This methodology contradicts with the dynamic models set up to explain global imbalances. Finally, almost all of the empirical papers exclusively focus on China, whereas during the global imbalances period of 2000s, Korea, Malaysia, Thailand, Indonesia, Singapore and Hong Kong all have similar growth experiences and net total capital outflows. ${ }^{2}$

This paper contributes to this literature by bringing sector- and firm-level evidence together to shed light on the micro foundations of different theories of global imbalances. Using firm-level data, we specifically test one key micro foundation in aggregate models of global imbalances with financial constraints such as Song, Storesletten, and Zilibotti (2011) and Buera and Shin (2009). These models aim at explaining the large current account surpluses in Asia based on either too high a corporate saving rate or too low a corporate invest-

\footnotetext{
${ }^{1}$ Relatedly, Sandri (2014) shows that the precautionary motive of entrepreneurs can explain capital outflow during the growth acceleration period; Bacchetta and Benhima (forthcoming) shows that, in a model with liquidity constraint, the demand for liquid foreign bond is complement to domestic investment, and this complementarity could explain capital outflows from fast-growing emerging economies.

${ }^{2}$ See Gourinchas and Jeanne (2013) and Alfaro, Kalemli-Ozcan, and Volosovych (2014).
} 
ment rate (or both). Their key building blocks are firm-level heterogeneity in productivity and financial constraints.

In Song, Storesletten, and Zilibotti (2011), private firms with high productivity are financially constrained and must rely on their own savings to finance investment, while stateowned enterprises (SOEs) with low productivity have access to external finance. In transition, entrepreneurs accumulate savings and increase their investment and employment, with investment constrained by savings; SOEs, on the other hand, reduce their investment and employment. This slow reallocation leads to a rise in aggregate savings-as entrepreneurs in private firms have a higher saving rate, and a decrease in aggregate investment-as SOEs are downsizing. The model therefore predicts a rising current account surplus during the transition. If a financial reform occurs in such a model, private firms will experience a decrease in savings relative to SOEs following the reform, leading to a decrease in aggregate savings.

In Buera and Shin (2009), after the removal of economic-wide distortions, the savings of high-productivity firms increase, as the low level of financial development hinders these firms' access to external finance. Meanwhile, low-productivity firms exit, causing a decline in investment. As a result, aggregate savings is higher than aggregate investment, leading to capital outflows. This paper implies that with successful broad financial reforms, productive firms now can enter and finance increasing investment with foreign savings. The self-financing saving motive would weaken and we should observe the current account surplus going down, together with a decline in savings. As a result, both models predict that financial reforms lead to capital inflows on net through a decline in savings, even though the original outflows might be driven by high savings or low investments.

To test the micro prediction of these theories, we use an extensive firm-level data set from several Asian countries during 2002-2011 from ORBIS, a commercial database provided by Bureau Van Dijk, which contains administrative data from business registries on millions of firms worldwide. The financial and ownership information in ORBIS is initially collected by local Chambers of Commerce and in turn, relayed to Bureau Van Dijk through some 40 different information providers. The database goes back in time for other countries but for our countries the data starts in 2002. ORBIS dataset is crucially different from the other data sets that are commonly used in the literature such as Compustat for the United States, Compustat Global, and Worldscope databases, in that 99 percents of the data in ORBIS covers private companies, whereas the former popular data sets are for large listed companies. A fundamental advantage of the data is to have type-specific ownership. We know not only the foreign and domestic owners of each company, but also whether a owner 
is government, business, or other types of entities, such as individual, private shareholder, foundation, or research institution. ${ }^{3}$

Given the fact that listed firms only amount to approximately 30 percent of the GDP in emerging economies on average (Bayoumi, Tong, and Wei, 2012), it is utmost essential to investigate the behavior of all firms. The reason to use Asian firms as our sample is that in order to test the key assumptions of the above theories we need to use emerging countries that went through financial reforms, with current account surpluses and productivity growth during the global imbalances period. For Asian economies we can also identify the ownership structure as SOEs versus private firms, which serves as proxy for firms' access to finance. ${ }^{4}$

We focus on reforms undertaken during the 2000s that are documented in the database of financial reform introduced in Abiad, Detragiache, and Tressel (2010), which is one of the most comprehensive cross-country data on financial liberalizations. ${ }^{5}$ There are two reasons for such a focus: first, during our sample period of the 2000s, which is also the key period for global imbalances, there was a push for financial liberalization and hence several of our countries undertook such reforms, though not all, providing us with control and treatment groups of firms from different Asian countries. Second, such reforms constitute a perfect laboratory to test the main assumption of the theories we describe above, that is financial frictions is the key factor driving capital outflow in these countries during the period of fast growth. If financial frictions led private firms to save more than SOEs originally then financial reforms that reduced such frictions should undo this behavior, as predicted by those models. Financial reforms might make SOEs less likely to obtain cheap bank loans, while at the same time make private entrepreneurs more likely to obtain bank loans, reducing their need for self-finance. This implication can in principle be tested with financial reforms that are undertaken at any time, however, by using this period we can also test the aggregate implications of firm-level heterogeneity in financial frictions for aggregate savings and hence for global imbalances.

We explicitly test whether savings at firm level differs by heterogeneity in credit constraints, conditional on firm-level productivity. We use a differences in differences strategy and investigate the effect of a removal of credit constraint on private firms' savings relative

\footnotetext{
${ }^{3}$ See Kalemli-Ozcan and others (2015) for details on the data including coverage and representation.

${ }^{4}$ The other set of countries where we can do a similar decomposition in the ownership structure is Latin America, but most of the financial reforms are much earlier than 2000s and hence we cannot measure the change in credit constraints during our sample period for firm-level data in a comparable way to the Asian countries.

${ }^{5}$ The data is originally constructed by Abiad and Mody (2005) and extended by Abiad, Detragiache, and Tressel (2010) to cover more countries and longer periods.
} 
to that of SOEs'. This approach will mimic the dynamic variation in firm-specific credit constraint, as implied by the models. The variation in the changes in credit constraint is driven by country-level financial reforms, exogenous to the selection of firms into SOE and non-SOE. Hence a private firm that was previously credit-constrained will face less severe a constraint after financial reforms. Provided that there was a similar prior trend before the reform in the saving decisions of state- and privately-owned firms (albeit their different average savings prior to the reform), we can deduce the differential effect of reforms on their savings. With rich panel data, we are able to control for firm and country-sector-year fixed effects, absorbing any firm-level trends that are different for SOEs and private firms, any country-year or sector-year policy changes or other country-sector-year shocks, and all long-run differences between SOEs and private firms, and identify only from within firm changes. We will also use both an unbalanced sample of firms and a continuing-firm sample to gauge the effects of entry and exit.

We find that financial reforms increased SOEs' savings relative to that of private firms'; alternatively, private firms decreased their savings relative to that of SOEs'. This result holds both for listed firms and for the full sample that includes non-listed firms. Our baseline point estimate suggests that a typical one-point increase in financial reform index resulted in a 0.8-percentage-point increase in the relative saving rate of SOEs'. This is a sizeable effect, a rise of about 25 percents over the mean saving rate. The finding is supportive of the micro foundations of the theories based on financial frictions.

The ratio of private credit to GDP increased by 5 percentage points on average in our countries after the financial reform period of 2005, based on the World Development Indicator. Hence it seems like reforms were successful on easing credit constraints to a certain extent. Our firm-level evidence shows that previously credit-constrained firms decreased their savings (or did not increase their savings as much) compared to previously unconstrained firms. The predictions of the aforementioned models are such that this micro channel will lead to a decline in aggregate corporate saving which will lead to a decline in aggregate saving and current account surplus. These aggregate predictions are not borne out in the data.

Figure 1 and Table 1 show that after the reform period of 2002-2005 (see Table 2 for dates of each reform), ${ }^{6}$ only 2 countries out of the 6 countries that undertook reforms relax-

\footnotetext{
${ }^{6}$ All our countries undertook several financial reforms during 2002-2005, the specific years are as follows: China, 2002 and 2004; India, 2004; Indonesia, 2003; Malaysia, 2003, 2004; Philippines, 2005; Taiwan, 2002, 2003; Thailand, 2003. Measures are direct measures to reduce financial frictions such as removal of interest rate control and security market reform.
} 
ing credit constraints-India and Indonesia—-had a deteriorating current account balance. ${ }^{7}$ All others have experienced increasing current account surpluses. Notice that if we end the period after reforms in 2008, the surpluses will be even higher given the current account reversals after the global financial crisis. Table 1 also reveals that India and Indonesia had experienced deteriorating current accounts due to a large increase in aggregate investmen$\mathrm{t}$, despite the fact that aggregate savings had also increased. In fact, as shown, in all our countries aggregate savings increased after the financial reform.

Table 3 shows sectoral saving and investment data for countries for which we have flowof-funds data. Again, similar to aggregate savings in Table 1, here we show that corporate savings increased in nearly all our countries after the financial reform. This result is not surprising since corporate savings is usually the biggest component of national saving in emerging markets (Karabarbounis and Neiman, 2014).

We further confirm these patterns in the data by aggregating our firm-level savings to 2-digit sector level and regressing sectoral corporate savings on financial reform. We show that corporate savings increased after financial reform in our countries, especially in sectors highly dependent on external finance. These findings cast doubt on the implications of the theory in terms of linking the key micro foundation based on firm heterogeneity in financial constraints to patterns in aggregate savings, where once credit-constrained firms start decreasing their savings, this effect should lead to a change in aggregate savings.

A possible explanation for our findings is that credit-constrained firms did not decrease their savings enough after reforms while unconstrained firms increased savings too much, leading to an increase in aggregate corporate savings. Across sectors, although compared to firms from sectors less dependent on external finance, previously constrained firms in sectors more dependent on external finance might have decreased their savings by more, previously unconstrained firms might also have increased their savings by more, possibly due to the increase in competition in credit and product markets resulting from reforms, or other factors, offsetting or even overturning the decrease in sectoral savings.

The rest of the paper is structured as follows. Section 2 summarizes the literature. Section 3 describes the methodology. Section 4 reviews the data. Section 5 presents the results and various robustness analysis. Section 6 concludes.

\footnotetext{
${ }^{7}$ Thailand's reform is a reversal, so it caused an increase in credit constraints; Taiwan reversed its private ownership reform in 2002 one year later.
} 


\section{Related Literature}

The empirical literature on global imbalances mostly focuses on the Chinese saving puzzle. Kuijs (2006) argues that the rise in corporate and government savings contributed more to the increase in national savins than the rise in household savings in China. Yang (2012) shows that from 2000 onwards the aggregate saving rate increased, moving above investment rate in China and once decomposed, all sectors-corporate, government, and household - contributed to the increase in saving. Focusing on the household sector, a large literature has identified different causes, such as income uncertainty, life-cycle saving motive, changing demographics, and sex ratio, for the high household saving rate in emerging economies (the last two explanations are more focused on China). ${ }^{8}$

In our analysis, we highlight the distinction between SOEs and private firms. This focus is motivated by the previous findings that SOEs are systematically different from private firms in terms of permanent differences. More specifically, empirical evidence suggests that compared to private firms, SOEs tend to be less productive, but have easier access to bank loans. ${ }^{9}$ In light of these findings, it is reasonable to expect that SOEs and private firms would make different saving decisions, and respond to the same financial reforms in different ways. ${ }^{10}$ In addition to financial reforms, emerging economies have also gone through several waves of structural reforms, and previous studies have examined the impacts of these reforms on the governance and performance of SOEs. ${ }^{11}$ However, we are unaware of studies that have used cross-country, over-time, firm-level data, to systematically examine the saving decision of SOEs and private firms, and study the differential impacts of financial reforms on this decision.

Bayoumi, Tong, and Wei (2012) investigates whether or not corporate savings can explain the increase in aggregate savings in China. They point out that all evidence that sug-

\footnotetext{
${ }^{8}$ See, for example, Chamon, Liu, and Prasad (2010), Chamon and Prasad (2010), Wei and Zhang (2011), Du and Wei (2013), Song and Yang (2010), Choukhmane, Coeurdacier, and Jin (2013) and Yang, Zhang, and Zhou (2011).

${ }^{9}$ Song, Storesletten, and Zilibotti (2011), using data from China National Bureau of Statistics Flow of Funds, shows that profits, return to capital, and employment are higher and rising in private firms compared to SOEs since 1998. Dollar and Wei (2007), using detailed survey data on 12,400 firms, though for a single year of 2005, also shows average return to capital to be twice as high in private firms as in fully state-owned enterprises. SOEs have also been documented to have easier access to bank loans, even many years after the market-oriented reforms (see, for example, Cull and Xu (2003), Song, Storesletten, and Zilibotti (2011), and Dollar and Wei (2007), among many others).

${ }^{10}$ In this paper, we do not attempt to look into what are the distortions that help SOEs sustain their low productivity or better access to external finance, but rather provide empirically sound estimates of an exogenous removal of certain distortions, i.e., credit constraints, on the differences between savings of firms that were credit-constrained and savings of firms that were not before the reform.

${ }^{11}$ See, for example, $\mathrm{Li}$ (1997) and reference thereto.
} 
gests corporate savings is the driving force of the high national savings in China is based on the flow-of-funds data from the National Bureau of Statistics of China. This data cannot be verified by a third party and is subject to frequent revisions that could change a number by as much as $20 \%$. They undertake a study using more than 1500 Chinese listed firms and more than 30000 global listed firms. They find that listed corporate firms in China are not different from listed firms elsewhere, and that the recent rise in corporate savings is part of a global trend, as also documented by Karabarbounis and Neiman (2014). Comparing SOEs and private firms in China they also find no significant difference in the saving decisions of these two groups.

Different from Bayoumi, Tong, and Wei (2012), we use a comprehensive database, in which listed companies account for only $20 \%$ of the final sample, and we are not interested in the Chinese corporate saving rate per se, but rather interested in how financial reforms affect SOEs and non-SOEs differently given our guidance by the theory. Through the use of country-sector-year effects, we fully control for rising trends in corporate savings, let it be global, country-specific, or country-sector-specific. This is an additional advantage of using firm-level panel data from multiple Asian countries. In fact, we can control for any smooth trend difference between SOEs and non-SOEs since our identification comes from discrete sudden changes in credit constraint, rather than the long run trend difference in the saving behaviors of SOEs and non-SOEs. We use firm fixed effects, allowing us to identify solely from overtime changes within a firm, as opposed to from cross-sectional long-run averages, as most existing literature does.

\section{Methodology}

We will employ a differences-in-differences methodology and estimate the following regression equation:

$$
\begin{aligned}
S_{i, c, j, t} & =\beta \text { SOE }_{i} \times \text { Reform }_{c, t}+\omega X_{i, c, j, t} \\
& +\varphi_{c, j, t}+\alpha_{i}+\xi_{i, c, j, t}
\end{aligned}
$$

where $i, c, j, t$ stand for firm, country, sector, and time respectively. $S_{i, c, j, t}$ denotes firmlevel savings, which is a flow variable normalized by the stock of total assets or tangible fixed assets (capital). $S O E_{i}$ is a dummy variable that indicates whether or not a firm is owned by the state. This dummy does not change overtime. Reform denotes financial 
reforms, which varies at country-time level. This variable is an index (score) for each country's current state of financial liberalization and it only changes (jumps discretely) in a given year if a reform is undertaken. $\varphi_{c, j, t}$ denotes country-sector-year fixed effects, in which sectors are at 2-digit-SIC level. These effects are important controls for any sector-level policies - such as subsidies and taxes-and also country-level policies-such as exchange rate valuations - that might affect results. $\alpha_{i}$ denotes firm fixed effects which means we identify from changes following reforms, rather than from permanent differences in savings rates between state- and privately-owned firms. We also control for time-varying firm-level variables in $X_{i, c, j, t}$ such as profitability/productivity, firm size, cash flow, and investment. Finally $\xi_{i, c, j, t}$ denotes the error term.

We control for the possibility that SOEs and non-SOEs were on different trends in terms of their savings before the reforms (or afterwards). This is important since the threat to our identification is not that SOE and non-SOE had permanent differences on many dimension$\mathrm{s}$ but rather they had different trends prior to reforms, or firms chose to become SOE or non-SOE as a result of financial liberalization. We rule out the later by construction as we keep the SOE ownership dummy fixed for each firm. To address the former concern, there are several ways. One can run a placebo exercise, control for the term $S O E_{i} *$ Trend, or use a control group of countries who did not go through any financial reforms. We adopt the latter approach here for space considerations, but in the previous version of this paper we show our results survive all these approaches. Specifically, we control for smooth trend differences between SOEs and non-SOEs through the use of the control group countries with no financial reforms during the period. If there were different trends for the saving decisions of SOEs and non-SOEs, to the extent that the trends were common to all countries in the sample regardless whether or not a country went through a reform or not, incorporating non-reform countries could help isolate the impacts of reforms from the trend. We also run our regressions without the control group countries and show that our results do not change. This further confirms that, without financial reforms, the differences between SOEs and non-SOEs are time invarying in nature and will be captured by firm fixed effects.

\section{Data and Sample}

In our analysis we will use firm-level data which includes information on firms' financial and ownership status. We will also use data on country-level financial reforms and industry-level measure for external finance dependence. This section introduces data sources and presents descriptive statistics. 


\subsection{Firm-Level Data}

We use the ORBIS database for firm-level analysis. The ORBIS database is compiled by BvD, and covers firms from many countries. The database includes companies' financial information in a standardized and internationally comparable format and their ownership information. The ownership information allows us to identify owners of a company and these owners' types, such as whether a owner is a public administration, an industrial company, or a financial institution. We use this ownership information to classify a firm as either a SOE or a non-SOE.

\subsubsection{Financial Information}

We use information from firms' financial statements to construct measures for firm savings and firm-level control variables that aim at capturing firm size, profitability, and cash flows. The ideal measure for firms' gross savings is "Retained Earnings" from the balance sheet, which is the historical stock of earnings that is not distributed, reported mostly by listed companies. Given our focus on non-listed companies, and given that the majority of our sample are private companies, however, we will use another balance sheet item-“'Other Shareholders' Fund" (hereafter OSHF) as a proxy for firms' gross savings. In balance-sheet accounting, Shareholders' Fund = Capital + Other Shareholders' Fund. OSHF thus includes not only retained earnings, but also treasury reserves, net depreciation, profit/loss for the fiscal year, voluntary provisions, and minority interests. All these items broadly capture how much a firm saves out of its profit.

Balance sheet items are stock variables. For ease of interpretation, in all regression$\mathrm{s}$, we convert stock savings into a flow measure by first differencing. We then normalize the change in firms' stock savings, $\triangle$ OSHF, by total assets to obtain a flow measure of firms' savings. The ratio of the change in OSHF over total assets is the benchmark measure, Savings ${ }_{1}$. In robustness analysis, we will also use a measure of firms' savings that is normalized differently using total tangible fixed assets (Savings $s_{2}$ ), or is based on retained earnings ( Savings $_{3}$ ), although in the later case our sample size will be much smaller.

\subsubsection{Ownership and Industry Information}

Our primary goal in this paper is to investigate the differential saving responses of SOEs and non-SOEs to financial reforms. It is thus crucial for us to obtain correct classifications for state ownership. ORBIS's unique ownership database allows us to classify firms based on both direct and indirect ultimate ownership information. To the best of our knowledge, 
this is the only data set available to us with such information that comprehends both listed and unlisted firms over time. In constructing firms' ownership status, we take into account that governments could indirectly hold the stock shares of a company through a state-owned enterprise, such as the China National Petroleum Corporation, or a sovereign wealth fund, such as the Temasek of Singapore. The data appendix describes this procedure in detail.

\subsubsection{Sample Coverage and Descriptive Statistics}

As discussed in the introduction, to focus on a region with important implications for global imbalances, we use the Asian segment of the ORBIS database. After excluding countries with poor coverage, we are left with a sample of eleven countries, namely Hong Kong, China, Taiwan, Singapore, Japan, Korea, India, Indonesia, Thailand, Philippines, and Malaysia. Among these, Hong Kong, Singapore, Japan, and Korea did not experience any reforms in our sample period, and they will naturally serve as the comparison group; the remaining countries will be the focus on our analysis. The initial sample covers close to one million firm-year observations since 2000. Our analysis requires ownership information and non-missing value for total assets and firms' savings, among other financial information. This restricts our analysis to a subset of this database. Even so, our sample covers a substantial share of the economy.

Table 4 reports several measures of our sample coverage for reform countries. Column 1 reports the share of listed companies. In all but two (India and Indonesia) of our sample countries, listed companies constitute less than half of the sample observations. In Thailand, Philippines, and Malaysia, listed companies accounts for $10 \%$ or less of our sample. Given our focus on the differential responses between SOEs and private companies in their saving decisions, it is important that we have a fair share of SOEs in all reform countries. Column 2 suggests this is indeed the case. There is substantial variation across countries in the shares of SOEs (for example, China has about a quarter SOEs in the sample, whereas Thailand has only about $2 \%$ ), but on average a country has 6-7 percents of observations that are state owned.

Columns 3 reports the fraction of the aggregate savings of our sample firms in GDP, where the aggregate firm-level savings is computed as the long run average of the yearto-year change in aggregate "Other Shareholders' Fund". Column 4 reports the aggregate corporative savings in national accounts, from the data set compiled by Karabarbounis and Neiman (2014), as a share of GDP. Column 5 reports our own collection of corporate savings from various sources of national flows-of-funds table. ${ }^{12}$ A comparison between Col-

\footnotetext{
${ }^{12}$ The differences between Columns 4 and Column 5 might be due to statistical discrepancies or small dif-
} 
umn 3, and Columns 4 and 5 suggests that our data is broadly representative in terms of corporate saving rate, given that the numbers are in the same order of magnitude. Again, there is heterogeneity in coverage across countries-China, for example, has worse coverage than other countries.

Column 6 reports the wage bill in our data relative to that in the official data. To focus on the role of financial frictions for firms' saving decisions, we exclude public administration, finance, and other services from our sample, as we will also do in subsequent empirical analysis. The remaining companies are mainly manufacturers. We use this sample of firm$\mathrm{s}$ to construct aggregate wage bill, and for a consistent comparison, use only aggregate manufacturing labor value added as the denominator. As Column 6 suggests, for countries like Taiwan, Malaysia, and India, our sample covers close to half of the manufacturing labor value added. For China and Indonesia, the coverage is not as good. But note that we construct the denominator (since official wage bill is not available) by multiplying the labor shares in the corporate sector estimated in Karabarbounis and Neiman (2014) and the manufacturing value added from the World Development Indicator. To the extent that manufacturing industries are less labor intensive than the corporate sector in general, our approach will overestimate the denominator, and understate our data coverage. In any event, in our robustness section we will do our regressions only for good coverage countries. This is important in terms of relating our micro results to macro dynamic patterns. ${ }^{13}$

Table 5 provides descriptive statistics for main variables used in the empirical analysis, both separately for SOE and private companies, and pooling both types. For each ratio, before statistics are generated, we trim the sample at $2 \%$ from both left and right to exclude outliers. The bottom panel of Table 5 tests whether the SOE sample is systematically different from the non-SOE sample.

The variables we focus on are firm size, profitability, investment rate, cash flow intensity, and three measures of firm saving rate. Firm size is measured in $\ln$ (total assets). Firms' investment rate is defined in a conventional way as $\frac{K_{t}-K_{t-1}}{K_{t-1}}$, where $\mathrm{K}$ is total tangible fixed asset. Cash flow and profitability are normalized by total assets as the literature commonly does. The three measures of firms' saving rate are: $\frac{\Delta \mathrm{OSHF}}{\text { Total Assets }}, \frac{\Delta \mathrm{OSHF}}{\mathrm{K}}$, and $\frac{\Delta \text { Retained Earnings }}{\text { Total Assets }}$. The first two measures are available for a substantial subset of our sample, while the third measure is available mainly for listed companies. We will use the first measure in our benchmark analysis, because the second measure might not be appropriate for many companies for whom non-tangible fixed assets constitute an important component of the balance sheet,

ferences in time horizon.

${ }^{13}$ See Kalemli-Ozcan and others (2015) on how to get good coverage and representation out of the ORBIS data in general. 
and the third measure has limited coverage. Indeed, as the top panel of Table 5 suggests, the second measure has a higher mean (which is not surprising, as tangible fixed assets are only a component of total assets), a higher dispersion, and a higher skewness.

The bottom panel of Table 5 reveals that SOE and private companies differ systematically in their size and cash flow intensity. In particular, SOEs are larger, have more cash, but do not necessarily invest more. The systematic difference in these dimensions calls for a fixed effect framework to remove these average differences between the two groups.

\subsection{Country-Level Financial Reforms}

Our measures for financial reforms are drawn from "A New Database of Financial Reforms" introduced by Abiad, Detragiache, and Tressel (2010). This database covers 91 countries over the period of 1973-2005. The database reports a composite index for financial liberalization, which is the sum of scores of seven sub-components, including credit controls and reserve requirements, interest rate controls, entry barriers, state/private ownership in baking sectors, security market policies, banking supervision and regulations, and restrictions on the capital account. Each dimension is graded on the scale of 0-3 based on whether the financial market is fully depressed (0), partially depressed (1), partially liberalized (2), fully liberalized (3). The aggregate index therefore takes a value of $0-21$. The aggregate index increases when there is a financial reform along one or more of the seven sub-components; a downward movement in the sub-component and aggregate score instead reflects a reversal. We use the aggregate index for benchmark regressions, and use the changes in the sub-components to examine the effects of different types of reforms.

Table 2 provides information on which country passed which reform and when. ${ }^{14}$ As we can see, during this period, most countries experience at least one point increase in the aggregate score; countries like Malaysia, China, experienced 3 points increase in this score, where, ideal for a differences-in-differences estimation, each change corresponds to a discrete jump in a given year. Even though the reforms are not frequent, the timing of reforms are different, from which we can identify their differential impacts. There can also be reversals: for example, in our sample, Thailand experienced a reversal in 2003 (restricting capital account).

To make sense of a one-point increase in the score for financial reforms, in the full sample (91 countries over the period of 32 years), the mean for overall score is 10.3 out of 21 , and the standard deviation is 6.33. So a one-point increase in the overall score is

\footnotetext{
${ }^{14}$ During this period, Japan, Hong Kong, Korea and Singapore, all of which are in our sample, experienced no financial reforms, and they will act as control groups in the diff-in-diff estimation.
} 
only $1 / 6$ of the standard deviation. For our reform countries for the period 2002-2005, the sample mean is 13.7 , with a standard deviation of 2.36 , so a one-point increase in overall score corresponds to less than a half of the standard deviation.

\subsection{Sectoral-Level External Finance Dependence}

In examining the role of financial frictions, we will also exploit industry dependence on external finance. Our measure of industry-level dependence on external finance is defined as the share of capital expenditures that is not financed by cash flow from operations. ${ }^{15}$ Originally from Rajan and Zingales (1998), this measure has been extensively used in studying the effects of financial development. A higher value for this measure means an industry relies more heavily on funding not directly from operations for investment, so this industry is more dependent on external finance.

The underlying assumption behind this approach is that industries differ in their dependence on external finance due to technological reasons. For example, industries could have different patterns in generating stable cash flows, hold assets that could be used as collateral in borrowing to varying degrees, or suffer from different types of contractual frictions, either between lenders and firms, or between the manager and owner of a firm. Given these industry-level characteristics, an economy-wide financial reform will affect these industries differently. This differential impact is thus informative about the role of financial development on both industry and aggregate outcomes.

To implement this approach, the key is to make sure the industry-level external finance dependence is not driven by the supply of finance, but instead determined by exogenous industry characteristics. Rajan and Zingales (1998) proposes to use U.S. listed companies to construct such a measure. As the U.S. is financially developed and also at the technological frontier, the decisions of U.S. listed companies are more likely due to exogenous industry technological characteristics, rather than reflecting the supply of finance.

Following Rajan and Zingales (1998), we construct a measure using the U.S. listed companies. Since our sample period are after 2000, we use the 1990-1999 data from the Compustat North America. One caveat of using the U.S. data to construct this measure, however, is that there might be cross-country differences in industry characteristics-the same product might be produced in dramatically different ways in our sample of Asian countries, it is thus not clear that the industry-level dependence measure constructed using the U.S. data is relevant for firms in the sample. To alleviate this concern, we also use our sample to construct this measure. More details in the construction of these two measures

\footnotetext{
${ }^{15}$ Formally, Dependence $=\frac{\text { Capital Expenditures-Cash Flow From Operations }}{\text { Capital Expenditures }}$
} 
are provided in the appendix.

\section{Empirical Analysis}

Table 6 shows our benchmark results. The saving rate used as dependent variable is measured as flow and normalized by assets. We adopt our preferred measure based on "Other Shareholders' Funding" here; later we test the results under alternative measures. In all regressions (and the regressions to be discussed below), we drop the observations with dependent variables falling in the top or bottom $2 \%$ of the distribution, to prevent outliers from affecting our results. Although not reported here, for robustness, we also try winsorization, or trimming at alternative percentiles, our results remain robust.

In the first column, we find a positive and statistically significant coefficient for the interaction between SOE dummy and financial reform, which means SOEs increased their savings more than non-SOEs following financial reforms. Or alternatively, non-SOEs decreased their savings more than SOEs. In Column 2 through 5, we control for other determinants of savings such as size, cash flow, productivity, and investment rate. To avoid simultaneity, we use lagged control variables, except for investment rate. The reason for using contemporaneous investment rate is that using lagged investment eliminates early years from the regression (given that we need 2-year-lagged capital stock to compute the lagged investment rate) and hence the identification would rely solely on the reforms from 2004 onwards. ${ }^{16}$

The signs of these control variables are as expected. Growing firms decreased their saving over time as captured by size; firms who increased their cash flow over time also decreased their savings over time, conditional on productivity improvements, proxied by profitability, an imperfect but commonly used measure in the finance literature. ${ }^{17}$ Finally, column 5 adds investment, measured in flow as the growth of capital stock. Again our main result does not change.

All regressions have firm fixed effects and country-sector-year fixed effects. In spite of the fact that fixed effects soak up a lot of variation, we have reasonable and precise point estimates. Our results are economically significant. The estimated coefficient of 0.8 implies that with a one-point increase in financial reform (which is the typical increase in the index when a single reform takes place), there is a 0.8 -percentage-point increase in savings. This represents a 25 -percent increase over pre-reform mean saving rate.

\footnotetext{
${ }^{16}$ However, we verify when including lagged investment rate as control, the result is qualitatively similar.

${ }^{17}$ Using sales growth, another imperfect but commonly used measure, gives us identical results.
} 
Table 7 undertakes robustness analysis. Column 1 excludes China to see how influential this country is for our estimation. Column 2 uses only countries with good coverage for which we have about half of the real economy, so China, Thailand and Philippines are not used in this column. Column 4 uses only continuing firms, meaning we do not allow entry and exit. Column 5 uses firms only from countries that went through financial reform, omitting control group countries. All estimates are significant and similar in magnitude. Column 6 restricts to only listed companies to see if listed and unlisted companies differ systematically. The coefficient is only slightly smaller, but still statistically significant. In the final two columns, we use two alternative measures of savings. In Column 7 we use Savings $_{2}$ as dependent variable, in which we use total tangible fixed assets-rather than total assets as in the benchmark regressions-for normalization. The coefficient is positive and significant with a point estimate three times larger than the benchmark results. However, notice from Table 5 that the median value of Savings ${ }_{2}$ is also about three times larger than the mean value of Savings ${ }_{1}$ (the mean value of Savings $s_{2}$ is much larger as this variable is skewed), so percentage wise, the results are almost the same. Finally, Column 8 uses Savings $_{3}$ - the measure based on changes in retained earnings—as dependent variable. The coefficient is about half of that from the benchmark specification. But again, given that the mean value of Savings ${ }_{3}$ is also much smaller than that of Savings ${ }_{1}$, the percentage effect is similar to that implied by the benchmark specification.

In summary, all robustness tests yield the consistent result that SOEs, compared to nonSOEs, increased their relative savings after the reforms, meaning SOEs either increased savings more, or decreased savings less. Moreover, across specifications, the quantitative magnitudes of the estimates are also similar.

\subsection{The Impacts of Specific Reforms}

So far we have focused on the impacts of an increase in the aggregate financial reform index. In this section, we further explore the impacts of specific reforms using information on the source of each increase in the aggregate score. To be able to include all lagged control variables, we focus on reforms after 2003. Table 8 reports the results. Column 1 replicates the benchmark specification; each column in Column 2-5 estimates the impact of one type of reforms. We obtain similar results as before that non-SOE firms decreased their savings more than SOE after the reforms. The point estimates, of course, differs across columns, which could be due to either the different natures of these reforms, or the heterogenous effects of financial reforms across countries. When we use all the reforms together in Column 6, it seems like interest rate control reform is most robust. This makes 
intuitive sense as interest rate control reform refers to relaxations in interest rate controls, defined based on whether the interest rates are set by administrations, through direct interest rate control, or through the use of interest floors, ceilings or bands. Of course, given the high correlation between reforms, and the fact they have been undertaken within 2-3 years' time in different countries, it is hard to pin down the direct effect of each. Our preferred measure is therefore the aggregate financial reform index.

\subsection{The Role of External Finance Dependence}

In this section we introduce the measure of external finance dependence from Rajan and Zingales (1998) into our regressions. Our aim is twofold. First, this will provide another measure of financial constraints, albeit at sector level, instead of our firm-level SOE/non-SOE split. We expect sectors that are more externally financial dependent to be more financially constrained before the reform, and to experience a larger change in financial constraints as the reform took place. Second, if what we have found in the previous section is truly due to financial reforms, we should expect that for industries that are more dependent on external finance, financial reforms should have a bigger effect. Therefore for firms that were more financial constrained (private companies), financial reforms should reduce savings even more in these externally dependent sectors.

Table 9 reports the results. Columns 1 and 2 use the Rajan and Zingales (1998) measure, constructed from the US listed firms data. As discussed before, given the large cross-country difference in production technology and management practise, the U.S. measure might fail to capture the true financial dependence in our sample countries, hence in Columns 3 and 4 we use the same measure constructed from our firm-level data. In Columns 1 and 3 we want to look at the direct impacts of reforms on industries with different external dependence, so we control for only country-year fixed effects and firm fixed effects; in Columns 2 and 4 we absorb this variation using country-sector-year fixed effects, and focus solely on the terms involving state ownership dummy.

In all four regressions, consistent with our earlier findings, the interaction between financial reforms and state ownership dummies has a positive and significant impacts on firm savings. The triple interaction terms among financial reform, external finance dependence, and state ownership dummy are also generally positive and significant, although the p-value is above the conventional cutoff in the first Column. These results imply that the relative savings of SOEs increased after financial reforms, and the relative increase was larger for SOEs operating in the financially dependent sectors. Alternatively, non-SOEs, especially those in the external-finance-dependent sectors, decreased their savings more relative to 
SOEs. Again, these results deliver the same message and strengthen our previous findings further.

So far we still cannot tell the source of the relative change in saving behaviors between SOEs and non-SOEs. The coefficients for the interaction term between financial reforms and industry financial dependence could shed some light on this. Note that this term in Columns 1 and 3 amounts to comparing over time two non-SOEs in two industries with different levels of external finance dependence. If the source of the differential impacts of financial reforms are through larger decreases in savings by private companies, we should expect such decreases to be more pronounced in industries where previous financial constraint was more severe-industries with higher external finance dependence. The fact that the interaction term between reform and dependence is not significant in either column suggests that it is unlikely that the changes in the saving behavior of non-SOEs are responsible for the results. Hence the results might be largely due to the increase in the savings of SOEs. This evidence is only suggestive, however, given that external finance dependence is measured with error, resulting in potential attenuation bias.

\subsection{Sector-Level Regressions}

In this section, we run regressions at sector level, instead of at firm level, to offer further evidence so that we could link our firm-level results to aggregate patterns shown in Tables 1 and 3 through the lens of the models we discuss earlier.

Specifically, in Tables 1 and 3, we report aggregate savings and aggregate corporate savings at the country-level and show that both increased after financial reforms for most countries. As shown in Table 4, where we aggregate our corporate savings to country-level and compare to data from national accounts, our data is representative. Hence here we aggregate our firm-level savings for each country-sector-year cell, where sector is at twodigit level, and regress that on financial reforms, which varies at the country-year level, to see if the sectoral aggregate savings increased after reforms. ${ }^{18} \mathrm{We}$ also interact the financial reform index with two measures of external finance dependence, as we do in the previous section, to sort out whether the relative change in savings in our firm-level regressions after the reform is due to non-SOEs decreasing their savings or SOEs increasing their savings. The reason why we do not run this regression at country level is that, in that case we will not be able to control for the different sectoral specializations of countries through country-

\footnotetext{
${ }^{18}$ Specifically, we aggregate total assets and "Other Shareholders' Fund" over firms in each each 2-digit industry, and then construct a measure of saving rate analogous to Savings $s_{1}$. In this aggregation, to keep the composition of sector fixed we focus on the sample of continuing firms. We winsorize the sample at top and bottom $2 \%$ to rule out the influence of outliers; the results are robust to trimming and winsorization choices.
} 
sector fixed effects. And of course we also will not be able to explore the differential effects of reforms on sectors with different external finance dependence. Still, one caveat in interpreting these sectoral regressions is that, while country-specific and industry-specific reforms would be captured by our fixed effects, we will not be able to rule out potential sectoral-level structural reforms implemented together with financial reforms.

Table 10 shows that after financial reform, sectoral savings went up at two-digit level in our countries on average. Columns 2 and 3 interact reforms with sector-level external dependence measures, one based on the U.S. and the other based on our own data. Columns 4 and 5 further add country-year fixed effects to absorb time-varying country shocks, including financial reforms, and focus on the interaction term. Both Column 2 and Column 3 show that savings increased after financial reforms. Column 2 and 4 also suggest that the increase was larger, if a sector is more dependent on external finance. One explanation consistent with this pattern, and all our previous results, is that, after financial reforms, previously unconstrained SOEs increased their saving, perhaps due to the reduced privilege in access to finance, or an increase in product market competition, resulting from financial reforms. This increase more than offset the decrease in the savings of private firms-in fact, the later effects might not be too strong to begin with, according to the results discussed in Section 5.2. Although SOEs do not constitute the majority of the firms in these sectors, if they increased their savings by a large factor, they can still account for bulk of the increase in savings in such sectors. In fact, Figure 2 shows the aggregate savings by SOEs and non-SOEs in our data and there was clearly a trend break after the reform period where in aggregate SOEs increased their savings faster than non-SOE. ${ }^{19}$ In micro data there is more heterogeneity and the firm-level results can still be both SOEs increasing their savings more or non-SOEs decreasing their savings more, but in the aggregate it seems like the increase in SOEs' savings dominated the dynamic patterns.

The interaction term between reform and finance dependence is not significant when we use the U.S. based measure (Columns 3 and 5). This might be due to the US based measure being more noisy in terms of capturing the need for external finance for our sample of firms,${ }^{20}$ and suffer from more severe attenuation bias. However, at the very minimum, our results at the country, sector, and firm level, collectively suggest that, the aggregate financial reforms did not trigger a decline in corporate savings, as predicted by theories that build on

\footnotetext{
${ }^{19}$ Figure 2 simply plots the aggregate OSHF for all firms classified as SOE and non-SOEs, with their values for the first year normalized to 1 . To rule out composition change we focus on the sample of continuing firms, but the same pattern exists for the full sample.

${ }^{20}$ The correlation between the two measures is 0.45 . The standard deviation for the two measures are 1.28 (U.S.-based measure) and 0.51 (our sample).
} 
the mechanism that credit-constrained firms decrease their savings relative to unconstrained firms after reforms (or increase relatively less), which holds in the firm-level data.

\section{Concluding Remarks}

Using an extensive firm-level data set that covers a substantial fraction of the economy from several Asian countries, we test whether the self-financing behavior of creditconstrained firms in rapidly growing emerging markets are responsible for the global imbalances. We estimate the effect of an exogenous change in credit constraints on firms' savings. As predicted by the theoretical models, after financial reforms, firms who were credit-constrained prior to the financial reforms that removed the constraint decreased their savings more, relative to firms that were not previously constrained. However, this firmlevel effect did not lead to a decrease in sectoral or aggregate corporate savings, nor a deterioration in aggregate current account surplus, as conjectured by the theory.

A possible explanation for our findings is that, while previously credit-constrained firm$s$ have decreased their savings after the removal of financial constraints, non-constrained firms have increased their savings more for other reasons, leading to an aggregate increase in corporate savings. Since we measure being "non-constrained" by government ownership (SOE), such firms might increase their savings after financial reform more than the decline in the savings of previously constrained firms due to the simple fact that financial reform will hinder their preferential access to credit. Or alternatively, previously constrained firms did not decrease their savings too much. Results from our sector-level regressions, which show that sectoral savings increased after reforms, are consistent with both interpretations. Further research that investigates the possible reasons behind the difference in savings between firms with different access to external finance, as a response to financial reforms, is needed.

\section{References}

Abiad, Abdul and Ashoka Mody, 2005, "Financial Reform: What Shakes It? What Shapes It?," American Economic Review, 95 (1), pp 66-88.

Abiad, Abdul G, Enrica Detragiache, and Thierry Tressel, 2010, "A New Database of Financial Reforms," IMF Staff Papers, 57 (2), pp 281-302. 
Aguiar, Mark and Manuel Amador, 2011, "Growth in the Shadow of Expropriation," The Quarterly Journal of Economics, 126 (2), pp 651-697.

Alfaro, Laura, Sebnem Kalemli-Ozcan, and Vadym Volosovych, 2014, "Sovereigns, Upstream Capital Flows, and Global Imbalances," Journal of European Economic Association, 12 (5), pp 1240-1284.

Bacchetta, Philippe and Kenza Benhima, forthcoming, "The Demand for Liquid Assets, Corporate Savings, and International Capital Flow," Journal of the European Economic Association.

Bayoumi, Tamim, Hui Tong, and Shang-Jin Wei, 2012, "The Chinese Corporate Savings Puzzle: A Firm-level Cross-country Perspective," in "Capitalizing China," University of Chicago Press, pp. 283-308.

Benigno, Gianluca and Luca Fornaro, 2012, "Reserve Accumulation, Growth and Financial Crises," CEPR Discussion Paper No. 9224.

Buera, Francisco J. and Yongseok Shin, 2009, "Productivity Growth and Capital Flows: The Dynamics of Reforms," NBER Working Paper No. 15268.

Caballero, Ricardo J., Emmanuel Farhi, and Pierre-Olivier Gourinchas, 2008, "An Equilibrium Model of "Global Imbalances" and Low Interest Rates," American Economic Review, 98 (1), pp 358-93.

Chamon, Marcos D. and Eswar S. Prasad, 2010, "Why Are Saving Rates of Urban Households in China Rising?," American Economic Journal: Macroeconomics, 2 (1), pp 93130.

Chamon, Marcos, Kai Liu, and Eswar S Prasad, 2010, "Income Uncertainty and Household Savings in China," NBER Working Paper No. 16565.

Choukhmane, Taha, Nicolas Coeurdacier, and Keyu Jin, 2013, "The One-Child Policy and Household Savings in China," CEPR Discussion Paper No. 9688.

Cull, Robert and Lixin Colin Xu, 2003, "Who Gets Credit? The Behavior of Bureaucrats and State Banks in Allocating Credit to Chinese State-owned Enterprises," Journal of Development Economics, 71 (2), pp 533-559.

Dollar, David and Shang-Jin Wei, 2007, "Das (Wasted) Kapital: Firm Ownership and Investment Efficiency in China," NBER Working Paper No. 13103. 
Dooley, Michael P, David Folkerts-Landau, and Peter Garber, 2007, "Direct Investment, Rising Real Wages and the Absorption of Excess Labor in the Periphery," in "G7 Current account imbalances: sustainability and adjustment," University of Chicago Press, pp. 103-132.

Du, Qingyuan and Shang-Jin Wei, 2013, "A Theory of the Competitive Saving Motive," Journal of International Economics, 91 (2), pp 275 - 289.

Gourinchas, Pierre-Olivier and Olivier Jeanne, 2013, "Capital Flows to Developing Countries: The Allocation Puzzle," The Review of Economic Studies, 80 (4), pp 1484-1515.

Kalemli-Ozcan, Sebnem, Bent Sorensen, Carolina Villegas-Sanchez, Vadym Volosovych, and Sevcan Yesiltas, 2015, "How to Construct Nationally Representative Firm Level Data from the ORBIS Global Database," NBER Working Paper No. 21558.

Karabarbounis, Loukas and Brent Neiman, 2014, "The Global Decline of the Labor Share," The Quarterly Journal of Economics, 129 (1), pp 61-103.

Kuijs, Louis, 2006, “How will China's Saving-Investment Balance Evolve?, World Bank Policy Research Working Paper No. 3958.

Li, Wei, 1997, "The Impact of Economic Reform on the Performance of Chinese State Enterprises, 1980-1989," Journal of Political Economy, 105 (5), pp 1080-1106.

Mendoza, Enrique G, Vincenzo Quadrini, and José-Víctor Ríos-Rull, 2009, "Financial Integration, Financial Development, and Global Imbalances," Journal of Political Economy, 117 (3), pp 371-416.

Rajan, Raghuram G and Luigi Zingales, 1998, "Financial Dependence and Growth," The American Economic Review, 88 (3), pp 559-586.

Sandri, Damiano, 2014, "Growth and Capital Flows with Risky Entrepreneurship," American Economic Journal: Macroeconomics, 6 (3), pp 102-123.

Song, Zheng and Dennis Tao Yang, 2010, "Life Cycle Earnings and Saving in a Fastgrowing Economy," Unpublished, Chinese University of Hong Kong.

_ , Kjetil Storesletten, and Fabrizio Zilibotti, 2011, "Growing Like China," The American Economic Review, 101 (1), pp 196-233. 
Wei, Shang-Jin and Xiaobo Zhang, 2011, "The Competitive Saving Motive: Evidence from Rising Sex Ratios and Savings Rates in China," Journal of Political Economy, 119 (3), pp 511-564.

Yang, Dennis Tao, 2012, “Aggregate Savings and External Imbalances in China," The Journal of Economic Perspectives, 26 (4), pp 125-146.

_ , Junsen Zhang, and Shaojie Zhou, 2011, "Why Are Saving Rates so High in China?," in “Capitalizing China," University of Chicago Press, pp. 249-278. 
Figure 1: Current Account/GDP

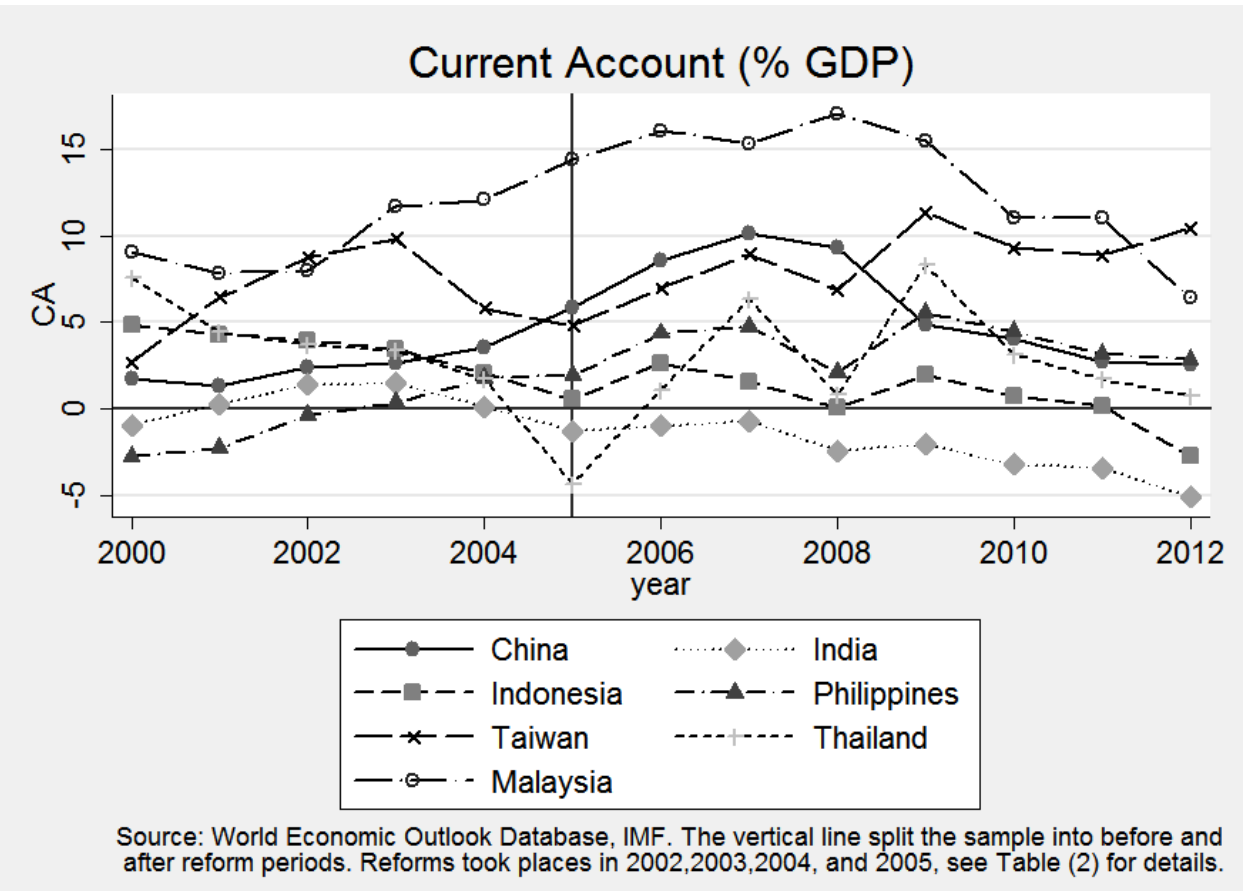


Figure 2: Aggregate Savings of SOEs and non-SOEs

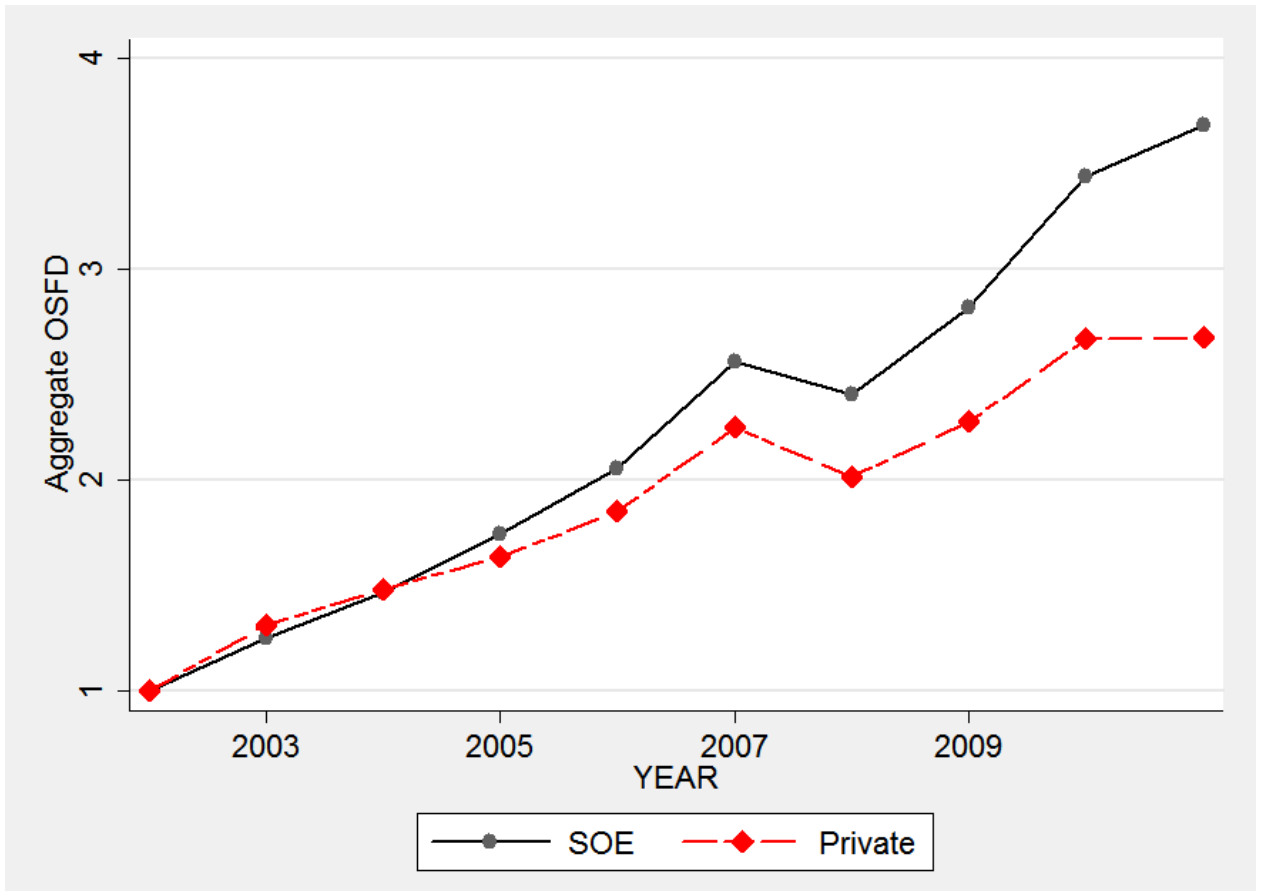

Table 1: Saving, Investment, and Current Account Surplus

\begin{tabular}{|c|c|c|c|c|c|c|}
\hline \multirow[t]{2}{*}{$(\%$ GDP $)$} & \multicolumn{2}{|c|}{ Saving } & \multicolumn{2}{|c|}{ Investment } & \multicolumn{2}{|c|}{ Current Account } \\
\hline & $2000-2005$ & 2006-2012 & $2000-2005$ & 2006-2012 & 2000-2005 & 2006-2012 \\
\hline China & 42.22 & 51.69 & 39.30 & 45.66 & 2.92 & 6.03 \\
\hline India & 27.23 & 33.40 & 27.06 & 35.97 & 0.17 & -2.57 \\
\hline Indonesia & 26.69 & 30.59 & 23.49 & 29.95 & 3.20 & 0.64 \\
\hline Malaysia & 34.56 & 35.74 & 24.04 & 22.51 & 10.52 & 13.22 \\
\hline Philippines & 21.63 & 22.88 & 21.85 & 18.99 & -0.23 & 3.90 \\
\hline Taiwan & 28.31 & 30.22 & 21.86 & 21.13 & 6.44 & 9.09 \\
\hline Thailand & 28.40 & 29.95 & 25.66 & 26.79 & 2.74 & 3.16 \\
\hline
\end{tabular}

Notes: This table presents average saving, investment, and current account surplus as percentage points of GDP for reform countries in our sample. We split the sample into two periods-during and after the period of financial reforms. Data source: World Economic Outlook Database, IMF. 
Table 2: The Dates of Financial Reforms

\begin{tabular}{|c|c|c|c|c|c|c|c|}
\hline & China & India & Indonesia & Malaysia & Philippines & Taiwan & Thailand \\
\hline \multirow[t]{2}{*}{ Financial Reforms-Overall } & 2002 & 2004 & 2003 & 2003 & 2005 & 2002 & 2003 \\
\hline & 2004 & & & 2004 & & 2003 & \\
\hline Interest Controls & 20022004 & - & - & 2004 & - & - & - \\
\hline Supervision in Banking Sector & - & - & - & - & - & 2003 & \\
\hline Private Ownership in Banking Sector & - & - & 2003 & - & 2005 & 2002, 2003(R) & - \\
\hline Capital Account Restrictions & - & 2004 & - & - & - & - & 2003(R) \\
\hline Entry Barriers & - & & & & & 2003 & \\
\hline Securities Market Policies & 2004 & - & - & 2003 & - & 2003 & - \\
\hline
\end{tabular}

Notes: This table presents the dates and types of financial reforms that took place during our sample period. The date of a reform (reversal) is defined as the year when a country experiences increase (decrease) in its aggregate financial reform index in the database for financial reform constructed by Abiad, Detragiache, and Tressel (2010). The aggregate financial reform index is a simple sum of seven variables, each measuring the openness of a country's financial market along one dimension. The seven dimensions are: credit controls, interest rate controls, entry barriers into the banking sector, private ownership in banking sector, banking prudential and supervision policies, capital account restrictions, and security market policies. (During the sample period no reforms in credit control took place, so it is omitted from the table.) Each dimension is rated on the scale of 0-3 based on whether the financial market is fully depressed (0), partially depressed (1), partially liberalized (2), fully liberalized (3). Hong Kong, Singapore, Japan, and Korea experienced no reforms during our sample period, hence are not included in this table. Reversals are indicated as " $R$ ". 
Table 3: Savings and Investment by Sector

\begin{tabular}{|c|c|c|c|c|c|c|c|c|c|c|c|c|}
\hline \multirow[b]{3}{*}{ (\% of GDP) } & \multicolumn{4}{|c|}{ Household } & \multicolumn{4}{|c|}{ Corporate } & \multicolumn{4}{|c|}{ Public } \\
\hline & \multicolumn{2}{|c|}{$2000-2005$} & \multicolumn{2}{|c|}{ 2006-2009 } & \multicolumn{2}{|c|}{$2000-2005$} & \multicolumn{2}{|c|}{ 2006-2009 } & \multicolumn{2}{|c|}{ 2000-2005 } & \multicolumn{2}{|r|}{ 2006-2009 } \\
\hline & $\mathrm{S}$ & I & $\mathrm{S}$ & I & $\mathrm{S}$ & I & $\mathrm{S}$ & I & $\mathrm{S}$ & I & $\mathrm{S}$ & I \\
\hline China & 20.96 & 9.48 & 23.55 & 9.22 & 20.05 & 25.93 & 22.12 & 30.12 & 0.93 & 3.89 & 5.24 & 4.91 \\
\hline India & 24.78 & 13.31 & 25.34 & 13.25 & 5.35 & 8.37 & 8.88 & 14.87 & 0.51 & 7.74 & 2.62 & 9.60 \\
\hline Malaysia & 0.52 & 4.25 & 0.75 & 3.43 & 26.17 & 12.64 & 32.80 & 12.17 & 2.65 & 6.24 & 3.01 & 4.31 \\
\hline Philippines & 7.90 & 4.74 & 7.08 & 5.13 & 9.34 & 9.40 & 9.05 & 6.45 & -1.05 & 2.28 & 2.17 & 2.74 \\
\hline Taiwan & 10.91 & N.A. & 10.03 & N.A. & 16.74 & 17.94 & 17.19 & 17.80 & 0.66 & 3.93 & 2.55 & 3.42 \\
\hline Thailand & 4.84 & 1.56 & 5.36 & 1.52 & 17.49 & 19.41 & 19.85 & 20.83 & 5.23 & 3.50 & 3.90 & 3.90 \\
\hline
\end{tabular}

Notes: This table reports sectoral saving and investment as percentage points of GDP for reform countries in our sample.

The data in this table is compiled from various statistical yearbooks and flows of funds accounts. We split the sample into two periods - during and after financial reforms. For China, Malaysia, Philippines, Taiwan, and Thailand, corporate sector includes both public and private enterprises, and public sector includes only government; for India, corporate sector includes only private enterprises, and public sector includes both government and public enterprise. For Taiwan, household sector do not form new capital. We do not have sectoral saving and investment information for Indonesia. Since the data sources used here are different from that in Table 1, there are small discrepancies between Table 1 and this table. 
Table 4: Data Coverage

\begin{tabular}{|c|c|c|c|c|c|c|}
\hline Country & $\begin{array}{l}\text { Listed Share } \\
\text { (1) }\end{array}$ & $\begin{array}{l}\text { SOE Share } \\
\text { (2) }\end{array}$ & $\begin{array}{l}\text { Corporate savings (ORBIS) } \\
\text { GDP } \\
\text { (3) }\end{array}$ & $\begin{array}{l}\text { Corporate Saving (KN) } \\
\text { (4) GDP }\end{array}$ & $\begin{array}{l}\text { Corporate Saving (FoF) } \\
\text { (5) GDP }\end{array}$ & $\begin{array}{l}\text { Wage bill(ORBIS) } \\
\text { Wage Bill (National Accounts) } \\
\text { (6) }\end{array}$ \\
\hline Taiwan & 0.43 & 0.09 & 0.10 & 0.13 & 0.17 & 0.58 \\
\hline Thailand & 0.01 & 0.02 & 0.10 & $\ldots$ & 0.16 & 0.10 \\
\hline Philippines & 0.02 & 0.03 & 0.10 & 0.15 & 0.10 & 0.11 \\
\hline Malaysia & 0.10 & 0.12 & 0.20 & $\ldots$ & 0.26 & 0.63 \\
\hline China & 0.40 & 0.22 & 0.04 & 0.19 & 0.21 & 0.05 \\
\hline India & 0.63 & 0.06 & 0.05 & $\ldots$ & 0.08 & 0.45 \\
\hline Indonesia & 0.76 & 0.06 & 0.003 & $\ldots$ & $\ldots$ & 0.04 \\
\hline
\end{tabular}

Notes: This table presents information on data coverage for reform countries. All values reported in this table are long-run average over the sample period. Columns 1-2 report the fraction of firms that are listed companies, and the fraction of firms with known ownership information that are state-owned, respectively. Column 3 reports the the aggregate savings of firms in our sample as a fraction of GDP, where the aggregate firm savings is computed as $\Delta$ OSHF (Other Shareholders' Fund). Column 4 reports the aggregate corporate-sector savings from the national accounts as a fraction of GDP, from the dataset compiled by Karabarbounis and Neiman (2014), for countries with data available for our sample period. Column 5 reports the same ratio, computed using the flows of funds data collected by the authors of this paper. The discrepancies between Columns 4 and 5 might be due to different data sources, or small differences in time horizon. Column 6 excludes public adminstration, finance, and other service companies, and computes the fraction of the aggregate wage bill of firms in the sample in aggregate manufacturing labor value added from national accounts. 
Table 5: Descriptive Statistics

\begin{tabular}{|c|c|c|c|c|c|}
\hline & & \#obs & mean & median & std \\
\hline \multirow[t]{7}{*}{ All } & Size & 246702 & 9.90 & 9.73 & 2.18 \\
\hline & Savings $_{1}$ & 207004 & 2.98 & 3.46 & 10.10 \\
\hline & Savings $_{2}$ & 199495 & 46.05 & 12.15 & 161.30 \\
\hline & Savings $_{3}$ & 60155 & 1.73 & 2.01 & 7.17 \\
\hline & Profitability & 242940 & 4.15 & 3.72 & 8.78 \\
\hline & Investment & 201456 & 17.92 & 3.71 & 61.42 \\
\hline & Cash Flow & 178892 & 6.94 & 6.15 & 7.70 \\
\hline \multirow[t]{7}{*}{ SOE } & Size & 11900 & 12.94 & 12.95 & 1.65 \\
\hline & Savings $_{1}$ & 10145 & 3.05 & 3.02 & 8.61 \\
\hline & Savings $_{2}$ & 10273 & 23.27 & 9.87 & 96.08 \\
\hline & Savings $_{3}$ & 9530 & 2.31 & 2.21 & 5.98 \\
\hline & Profitability & 11802 & 4.15 & 3.67 & 7.10 \\
\hline & Investment & 10237 & 17.54 & 8.15 & 42.35 \\
\hline & Cash Flow & 11107 & 7.44 & 6.79 & 6.43 \\
\hline \multirow[t]{7}{*}{ Non-SOE } & Size & 234802 & 9.75 & 9.60 & 2.09 \\
\hline & Savings $_{1}$ & 196859 & 2.98 & 3.49 & 10.17 \\
\hline & Savings $_{2}$ & 189222 & 47.28 & 12.30 & 164.01 \\
\hline & Savings $_{3}$ & 50625 & 1.62 & 1.96 & 7.37 \\
\hline & Profitability & 231138 & 4.15 & 3.72 & 8.85 \\
\hline & Investment & 191219 & 17.94 & 3.46 & 62.28 \\
\hline & Cash Flow & 167785 & 6.91 & 6.09 & 7.77 \\
\hline \multirow[t]{8}{*}{ Mean Test } & & diff. & t stat & & \\
\hline & Size & 3.20 & 160 & & \\
\hline & Savings $_{1}$ & 0.08 & 0.73 & & \\
\hline & Savings $_{2}$ & -24.01 & -14.70 & & \\
\hline & Savings $_{3}$ & 0.69 & 8.67 & & \\
\hline & Profitability & 0.00 & 0.02 & & \\
\hline & Investment & -0.40 & -0.64 & & \\
\hline & Cash Flow & 0.54 & 7.10 & & \\
\hline
\end{tabular}

Notes: This table presents descriptive statistics. Size is defined as $\ln$ (Total Assets). Savings $_{1}$ is defined as $\frac{\mathrm{OSHF}_{t}-\mathrm{OSHF}_{t-1}}{\text { Total Assets }}(\%)$, where OSHF refers to Other Shareholders' Funds in financial statements; Savings $s_{2}$ is defined as $\frac{\mathrm{OSHF}_{t}-\mathrm{OSHF}_{t-1}}{\text { Tangible Fixed Assets }}{ }_{t}(\%)$; Savings 3 is defined as $\frac{\text { Retearn }_{t}-\text { Retearn }_{t-1}}{\text { Total Assets }_{t}}(\%)$, where Retearn refers to firms' Retained Earnings in the balance sheet. Profitability is defined as $\frac{\text { Profit }}{\text { Total Assets }}(\%)$; Investment Rate is defined as $\frac{K_{t}-K_{t-1}}{K_{t-1}}(\%)$, where $K$ is total tangible fixed assets; Cash Flow is defined as $\frac{\text { Cash Flow }}{\text { Total Assets }}(\%)$. For each variable except total assets, the sample is trimmed at two percents from both the top and the bottom to exclude outliers. The bottom panel of the table reports the mean difference between SOE and non-SOEs and the corresponding $t$ statistics. 
Table 6: The Impacts of Overall Financial Reforms on Firms' Savings

\begin{tabular}{lccccc}
\hline Dependent Variable: & \multicolumn{5}{c}{ Savings $_{1}$} \\
\cline { 2 - 6 } & $(1)$ & $(2)$ & $(3)$ & $(4)$ & $(5)$ \\
\hline FinancialReform*SOE & $0.731^{* * *}$ & $0.848^{* * *}$ & $0.817^{* * *}$ & $0.830^{* * *}$ & $0.822^{* * *}$ \\
& $(0.186)$ & $(0.205)$ & $(0.223)$ & $(0.226)$ & $(0.222)$ \\
Size $_{t-1}$ & & $-0.019^{* * *}$ & $-0.022^{* * *}$ & $-0.022^{* * *}$ & $-0.023^{* * *}$ \\
& & $(0.003)$ & $(0.003)$ & $(0.003)$ & $(0.003)$ \\
Cash Flow $_{t-1}$ & & & $0.002^{* *}$ & $-0.635^{*}$ & $-0.724^{*}$ \\
& & & $(0.001)$ & $(0.340)$ & $(0.432)$ \\
Profitability & & & & $0.017^{*}$ & $0.019^{*}$ \\
& & & & $(0.009)$ & $(0.011)$ \\
Investment $_{t}$ & & & & & $0.000^{* * *}$ \\
& & & & & $(0.000)$ \\
\hline Observations $^{2}$ & 207004 & 207001 & 157629 & 157627 & 157276 \\
$\mathrm{R}^{2}$ & 0.361 & 0.366 & 0.374 & 0.375 & 0.376 \\
Firm FE & yes & yes & yes & yes & yes \\
Country-sector-year FE & yes & yes & yes & yes & yes \\
\hline
\end{tabular}

Notes: This table reports the effects of financial reforms on SOEs' saving decisions relative to that of nonSOEs'. The dependent variable is the year-to-year change in other shareholders' funds (OSHF), divided by current-period total assets, multiplied by 100 . The dependent variable is trimmed at $2 \%$ from both the top and the bottom to exclude outliers. Size is defined as $\ln$ (total assets); Cash Flow, Profitability are normalized by total assets and multiplied by 100 . Investment is defined as $\frac{K_{t}-K_{t-1}}{K_{t-1}}(\%)$. All regressions control for country-sector-year fixed effects, where sector classifications are at 2-digit level according to SIC.

Standard errors (clustered at the country-year level) in parentheses.

${ }^{*} p<0.10,{ }^{* *} p<0.05,{ }^{* * *} p<0.01$ 
Table 7: Robustness: Alternative Measures of Savings and Different Samples

\begin{tabular}{|c|c|c|c|c|c|c|c|c|}
\hline \multirow[t]{3}{*}{ Dependent Variable: } & \multicolumn{6}{|c|}{$\overline{\text { Savings }_{1}}$} & \multirow{3}{*}{$\begin{array}{c}\text { Savings }_{2} \\
(7) \\
\text { Benchmark }\end{array}$} & \multirow{3}{*}{$\begin{array}{c}\text { Savings }_{3} \\
(8) \\
\text { Benchmark }\end{array}$} \\
\hline & (1) & (2) & (3) & (4) & (5) & (6) & & \\
\hline & No China & Coverage & Crisis & Continuing & Reform & Listed & & \\
\hline \multirow[t]{2}{*}{ FinancialReform*SOE } & $1.689^{* *}$ & $1.827^{* * *}$ & $1.077^{* * *}$ & $0.894^{* * *}$ & $0.707^{* * *}$ & $0.619^{* *}$ & $3.69^{*}$ & $0.343^{*}$ \\
\hline & $(0.668)$ & $(0.650)$ & $(0.218)$ & $(0.265)$ & $(0.166)$ & $(0.295)$ & $(2.05)$ & $(0.197)$ \\
\hline \multirow[t]{2}{*}{$\operatorname{Size}_{t-1}$} & $-0.021^{* * *}$ & $-0.022^{* * *}$ & $-0.017^{* * *}$ & $-0.022^{* * *}$ & $-0.032^{* * *}$ & $-0.030^{* * *}$ & $-0.285^{* * *}$ & $-0.018^{* * *}$ \\
\hline & $(0.004)$ & $(0.004)$ & $(0.005)$ & $(0.004)$ & $(0.004)$ & $(0.003)$ & $(0.030)$ & $(0.002)$ \\
\hline \multirow[t]{2}{*}{ Cash Flow $_{t-1}$} & $-0.557^{*}$ & $-1.11^{* * *}$ & -0.270 & $-0.626^{*}$ & -0.125 & $-0.861^{* *}$ & -0.037 & -0.114 \\
\hline & $(0.331)$ & $(0.35)$ & $(0.193)$ & $(0.366)$ & $(0.171)$ & $(0.350)$ & $(0.027)$ & $(0.113)$ \\
\hline \multirow{2}{*}{ Profitability $_{t-1}$} & $0.016^{*}$ & $0.035^{* * *}$ & 0.007 & $0.016^{*}$ & 0.003 & $0.023^{* *}$ & 0.043 & 0.003 \\
\hline & $(0.009)$ & $(0.011)$ & $(0.005)$ & $(0.010)$ & $(0.004)$ & $(0.009)$ & $(0.031)$ & $(0.003)$ \\
\hline Observations & 146292 & 141063 & 103301 & 118876 & 41516 & 47916 & 151464 & 58549 \\
\hline $\mathrm{R}^{2}$ & 0.376 & 0.374 & 0.430 & 0.336 & 0.428 & 0.418 & 0.469 & 0.427 \\
\hline Firm FE & yes & yes & yes & yes & yes & yes & yes & yes \\
\hline Country-sector-year FE & yes & yes & yes & yes & yes & yes & yes & yes \\
\hline
\end{tabular}

Notes: This table reports robustness tests of results reported in Table 6. Savings 1 is defined as $\frac{\mathrm{OSHF}_{t}-\mathrm{OSHF}_{t-1}}{\mathrm{Total}_{\mathrm{Asset}}}(\%)$, where OSHF refers to Other Shareholders

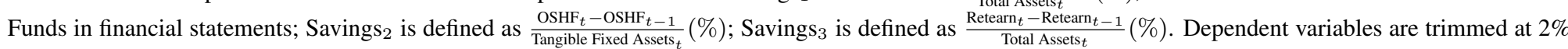
from both the top and the bottom to exclude outliers. Size is defined as $\ln ($ total assets); Cash Flow, Profitability are normalized by total assets and multiplied by 100.

Columns 1-6 report the estimates using the benchmark measure of firm saving, and the estimates should be compared to Column 4 of Table 6 . Column 1 excludes China from the regression; Column 2 excludes all reform countries whose coverage are relatively low, i.e., China, Thailand, Philippines, and Indonesia; Column 3 restricts the regression to before 2008, hence excluding the recent financial crisis; Column 4 restricts the regression to a continuing sample of firms that are present in the data for at least 9 years out of the 10-year sample period; Column 5 restricts the regression to the sample of reform countries in Table 2; Column 6 restricts the regression to listed companies. Columns 7-8 report the estimates using Savings $_{2}$ and Savings $_{3}$, respectively. Column (8) has substantial fewer observations than the benchmark specification because retained earnings are reported mostly for listed companies.

All regressions control for country-sector-year fixed effects, where sector classifications are at 2-digit level according to SIC.

Standard errors (clustered at the country-year level) in parentheses.

${ }^{*} p<0.10,{ }^{* *} p<0.05,{ }^{* * *} p<0.01$ 
Table 8: Effects of Different Types of Financial Reforms

\begin{tabular}{|c|c|c|c|c|c|c|}
\hline \multirow[t]{3}{*}{ Dependent Variable: } & \multicolumn{6}{|c|}{ Savings $_{1}$} \\
\hline & (1) & (2) & (3) & $(4)$ & (5) & (6) \\
\hline & Overall & Interest Control & Privatization & Capital Account & Security Market & All \\
\hline Financial Reform *SOE & $\begin{array}{c}0.830^{* * *} \\
(0.226)\end{array}$ & & & & & \\
\hline Interest Control $*$ SOE & & $\begin{array}{c}1.287^{* * *} \\
(0.300)\end{array}$ & & & & $\begin{array}{c}1.459^{* * *} \\
(0.512)\end{array}$ \\
\hline Private Banking*SOE & & & $\begin{array}{l}13.861^{*} \\
(7.238)\end{array}$ & & & $\begin{array}{l}13.864^{*} \\
(7.239)\end{array}$ \\
\hline Capital Accounts*SOE & & & & $\begin{array}{l}2.581^{* *} \\
(1.010)\end{array}$ & & $\begin{array}{l}2.582^{* *} \\
(1.010)\end{array}$ \\
\hline Security Market *SOE & & & & & $\begin{array}{c}1.224^{* * *} \\
(0.354)\end{array}$ & $\begin{array}{l}-0.217 \\
(0.579)\end{array}$ \\
\hline $\operatorname{Size}_{t-1}$ & $\begin{array}{c}-0.022^{* * *} \\
(0.003)\end{array}$ & $\begin{array}{c}-0.022^{* * *} \\
(0.003)\end{array}$ & $\begin{array}{c}-0.022^{* * *} \\
(0.003)\end{array}$ & $\begin{array}{c}-0.022^{* * *} \\
(0.003)\end{array}$ & $\begin{array}{c}-0.022^{* * *} \\
(0.003)\end{array}$ & $\begin{array}{c}-0.022^{* * *} \\
(0.003)\end{array}$ \\
\hline Cash Flow $_{t-1}$ & $\begin{array}{c}-0.635^{*} \\
(0.340)\end{array}$ & $\begin{array}{c}-0.635^{*} \\
(0.341)\end{array}$ & $\begin{array}{c}-0.634^{*} \\
(0.340)\end{array}$ & $\begin{array}{c}-0.634^{*} \\
(0.340)\end{array}$ & $\begin{array}{c}-0.634^{*} \\
(0.340)\end{array}$ & $\begin{array}{c}-0.635^{*} \\
(0.341)\end{array}$ \\
\hline Profitability $_{t-1}$ & $\begin{array}{l}0.017^{*} \\
(0.009)\end{array}$ & $\begin{array}{l}0.017^{*} \\
(0.009)\end{array}$ & $\begin{array}{l}0.017^{*} \\
(0.009)\end{array}$ & $\begin{array}{l}0.017^{*} \\
(0.009)\end{array}$ & $\begin{array}{l}0.017^{*} \\
(0.009)\end{array}$ & $\begin{array}{l}0.017^{*} \\
(0.009)\end{array}$ \\
\hline Observations & 157627 & 157627 & 157627 & 157627 & 157627 & 157627 \\
\hline $\mathrm{R}^{2}$ & 0.375 & 0.375 & 0.375 & 0.375 & 0.375 & 0.375 \\
\hline Firm FE & yes & yes & yes & yes & yes & yes \\
\hline Country-sector-year FE & yes & yes & yes & yes & yes & yes \\
\hline
\end{tabular}

Notes: This table reports the estimates for the differential effects of a financial reform on SOE and private companies using different sub-dimensions of reform. The first column replicates Column 4 in Table 6. Columns 2-5 use interest control reform, banking-sector privatization reform, capital account restriction reform, and security market reform, respectively. Column (6) includes all reforms. The dependent variable in the regressions reported in this table is the year-to-year change in other shareholders' funding (OSHF), divided by current-period total assets, multiplied by 100 . The dependent variable is trimmed at $2 \%$ from both the top and the bottom to exclude outliers. Size is defined as $\ln ($ total assets); Cash Flow, Profitability are normalized by total assets and then multiplied by 100. All regressions control for country-sector-year fixed effects, where sector classifications are at 2-digit level according to SIC.

Standard errors (clustered at the country-year level) in parentheses. ${ }^{*} p<0.10,{ }^{* *} p<0.05,{ }^{* * *} p<0.01$ 
Table 9: Financial Reform, Sectoral Dependence, and Savings

\begin{tabular}{|c|c|c|c|c|}
\hline \multirow[t]{3}{*}{ Dependent Variable: } & \multicolumn{4}{|c|}{ Savings $_{1}$} \\
\hline & \multicolumn{2}{|c|}{ U.S.-based measure } & \multicolumn{2}{|c|}{ Sample-based measure } \\
\hline & (1) & (2) & (3) & (4) \\
\hline FinancialReform*SOE & $\begin{array}{c}0.646^{* * *} \\
(0.227)\end{array}$ & $\begin{array}{c}0.671^{* * *} \\
(0.221)\end{array}$ & $\begin{array}{c}0.987^{* * *} \\
(0.238)\end{array}$ & $\begin{array}{c}1.125^{* * *} \\
(0.265)\end{array}$ \\
\hline Reform$^{*}$ Dependence $_{1}$ & $\begin{array}{c}0.001 \\
(0.090)\end{array}$ & & & \\
\hline 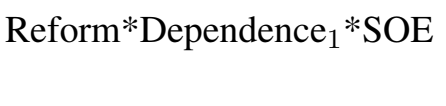 & $\begin{array}{c}0.186 \\
(0.119)\end{array}$ & $\begin{array}{c}0.268^{* *} \\
(0.103)\end{array}$ & & \\
\hline Reform$^{*}$ Dependence 2 & & & $\begin{array}{l}-0.767 \\
(0.725)\end{array}$ & \\
\hline Reform$^{*}$ Dependence ${ }_{2} * \mathrm{SOE}$ & & & $\begin{array}{l}2.044^{*} \\
(1.157)\end{array}$ & $\begin{array}{l}2.517^{* *} \\
(1.249)\end{array}$ \\
\hline Size $_{t-1}$ & $\begin{array}{c}-0.021^{* * *} \\
(0.004)\end{array}$ & $\begin{array}{c}-0.022^{* * *} \\
(0.003)\end{array}$ & $\begin{array}{c}-0.021^{* * *} \\
(0.004)\end{array}$ & $\begin{array}{c}-0.022^{* * *} \\
(0.003)\end{array}$ \\
\hline Cash Flow ${ }_{t-1}$ & $\begin{array}{l}-0.645^{*} \\
(0.341)\end{array}$ & $\begin{array}{c}-0.635^{*} \\
(0.340)\end{array}$ & $\begin{array}{l}-0.645^{*} \\
(0.341)\end{array}$ & $\begin{array}{l}-0.635^{*} \\
(0.341)\end{array}$ \\
\hline Profitability $_{t-1}$ & $\begin{array}{l}0.017^{*} \\
(0.009)\end{array}$ & $\begin{array}{l}0.017^{*} \\
(0.009)\end{array}$ & $\begin{array}{l}0.017^{*} \\
(0.009)\end{array}$ & $\begin{array}{c}0.017^{*} \\
(0.009)\end{array}$ \\
\hline Observations & 157627 & 157627 & 157627 & 157627 \\
\hline $\mathrm{R}^{2}$ & 0.360 & 0.375 & 0.360 & 0.375 \\
\hline Firm FE & yes & yes & yes & yes \\
\hline Country-sector-year FE & - & yes & - & yes \\
\hline Country-year FE & yes & - & yes & - \\
\hline
\end{tabular}

Notes: This table estimates the differential impacts of financial reforms on the saving decisions of SOE and private companies in sectors with different external finance dependence. The measure for external finance dependence is based on Rajan and Zingales (1998), defined as the fraction of capital expenditures not financed by cash flows from operation. The measure used in Columns 1-2 (Dependence ${ }_{1}$ ) is constructed using the U.S. listed companies, over the period of the 1990s.

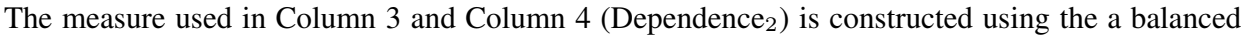
sub-sample of listed companies (restricted to before-crisis period) from our sample. The dependent variable is trimmed at $2 \%$ from both the top and the bottom to exclude outliers. Size is defined as ln(total assets); Cash Flow and Profitability are normalized by total assets and multiplied by 100 . Column 1 and Column 3 control for country-year fixed effects; Column 2 and Column 4 control for country-sector-year fixed effects, where sector classifications are at 2-digit level according to SIC. Standard errors (clustered at the country-year level) in parentheses.

${ }^{*} p<0.10,{ }^{* *} p<0.05,{ }^{* * *} p<0.01$ 
Table 10: Reforms and Industry-level Savings

\begin{tabular}{lccccc}
\hline Dependent Variable & \multicolumn{5}{c}{ Country-Industry Savings 1} \\
\cline { 2 - 4 } Estimator & $(1)$ & $(2)$ & $(3)$ & & \multicolumn{3}{c}{$\mathrm{S}^{*} \mathrm{C}+\mathrm{S}^{*} \mathrm{~T}+\mathrm{C} * \mathrm{~T}$} \\
\cline { 2 - 4 } \cline { 6 - 7 } & $1.495^{* *}$ & $1.854^{* *}$ & $1.507^{* *}$ & & $(5)$ \\
\hline Financial Reform & $(0.691)$ & $(0.786)$ & $(0.697)$ & & \\
& & $2.571^{* *}$ & & $2.806^{* *}$ & \\
Reform*Dependence $_{2}$ & & $(1.230)$ & & $(1.216)$ & \\
& & & 0.519 & & 0.574 \\
Reform*Dependence $_{1}$ & & & $(0.590)$ & & $(0.586)$ \\
& 2014 & 2014 & 2014 & 2014 & 2014 \\
\hline Observations & 0.39 & 0.39 & 0.39 & 0.47 & 0.47 \\
$\mathrm{R}^{2}$ & &
\end{tabular}

Notes: The dependent variable is corporate savings computed at the country-industry-year level. In aggregation we include only a continuing sample of firms to rule out the role of entry into and exit from the database. We aggregate firm-level OSHF (Other Shareholders' Funds) and Total Assets by country-industry-year, and then use this to compute industry-level saving rate analogous to Savings $s_{1}$. The dependent variable is then winsorized at $2 \%$ from both ends to drop outliers. Column 1 includes only Financial Reform as dependent variable; Columns 2-3 include in addition the interaction term between financial reform and sectoral-level external finance dependence; Columns 4-5 further add country-year fixed effects. The definitions of Dependence ${ }_{1}$ and Dependence $_{2}$ are described in the footnote of Table 9.

Estimator indicates the set of fixed effects that are used in these regressions: $\mathrm{S}$ indicates sector fixed effects; $\mathrm{C}$ indicates country fixed effects; $\mathrm{T}$ indicates time fixed effects.

Standard errors (clustered at the country-year level) in parentheses. ${ }^{*} p<0.10,{ }^{* *} p<0.05,{ }^{* * *}$ $p<0.01$ 


\section{A Data Appendix}

\section{A.1 Firm-Level Data}

\section{A.1.1 Data Preparations}

Our firm-level financial information is obtained in the "Global Detailed Form" (for listed companies), and the "Global Standard Form" (for private companies), from the ORBIS database. For listed companies, the financial information include all detailed items on the balance sheet and the profit/loss accounts. For private companies, the information is coarser.

For the majority of companies in our sample, the financial information is from December of each year. Some companies, however, report their financial information in other months. For the companies whose financial information are from months before June, we change the year of information to the year before the time of report. For example, if a company reports a profit of 1 million in May, 2013, we count this as its profit for the year of 2012.

There is enormous heterogeneity in the firm-level variables. To prevent outliers from affecting our analysis, in all our firm-level regression analysis, we trim our dependent variables at $2 \%$ from both the top and the bottom. A $2 \%$ trimming makes the distributions of dependent variables look approximately normal. Although not reported here, for robustness, we also try winsorizing the outliers, and the results are robust. The descriptive statistics in Table 5 is based on the sample after trimming and dropping the observations for which we do not have ownership information. We also further exclude public administrations, finance, and other service industries in both computing descriptive statistics and performing regression analysis.

\section{A.1.2 Constructing the State Ownership Status}

We proceed as follows to classify the ownership status of the firms in our sample.

First, we find companies whose global ultimate owner is recorded in the BvD Ownership Database. In extracting the information, we require a minimum of $25 \%$ shares along each link. We generate $\mathrm{SOE}_{1}$ based on the type of this ultimate owner: if a company's ultimate owner is recorded as "public authority, government," we assign a value of 1 to this variable, otherwise we assign a value of 0 to it. In the case where a company's ultimate owner is missing, or the type of the ultimate owner is unclear, we leave $\mathrm{SOE}_{1}$ with missing value.

Second, we use the information from step 1 to update the type of each companies' 
shareholders. So if company B-a shareholder of company A-has an ultimate owner being "Public Authority," we change the type of company B to "Public Authority" as well, even though B itself might be an "Industry Company" or "Financial Company." This procedure serves to capture to the maximum extent the possibility that government authorities may hold companies indirectly through either industry company, financial companies or other type of entities. In this case, the ownership goes as Government-B-A, and B is the intermediary through which the government control A, so we update B's type to "Public Authority."

Third, we also create $\mathrm{SOE}_{2}$, and set this variable to 1, if firm's biggest direct shareholder in a given year is recorded as "Public Authority,". The difference here is that this dummy is based on direct shareholder, while the previous $\mathrm{SOE}_{1}$ is based on ultimate ownership. The shareholder data is in principle by firm-year, but there is limited over-time variation in ownership status. We use shareholder information from the last year of the sample and fix the ownership status for each firm for the entire sample period. This also prevents endogenous change in ownership as a response to financial reforms.

Finally, we determine firms' type based on $\mathrm{SOE}_{1}$ and $\mathrm{SOE}_{2}$. As we are more confident in $\mathrm{SOE}_{1}$, when the two dummies differ, we use $\mathrm{SOE}_{1}$. In a robustness check we run regression with $\mathrm{SOE}_{2}$ only, and our results do not change.

\section{A.2 Measure for External Finance Dependence}

We construct the Rajan-Zingales measure for industries-level external finance dependence using two different samples.

The first measure is generated using a sample of U.S. listed companies. We focus on Compustat North America database, and extract all observations between 1990 and 1999. We aggregate firm-level capital expenditures and cash flows from operations over the ten years to flush out yearly fluctuations, and use that to generate firm-level dependence on external finance, following the formula:

Dependence $=($ Capital Expenditures- Cash Flows from Operations $) /$ Capital Expenditures

We take the median of this value for each industry, dropping industries with only one firm, and use this median value as our first measure of industry external finance dependence.

The second measure is generated using our own sample of firms. To capture the technological frontier in our sample of countries, we focus on the listed companies, as those are with best access to finance in any given industry. To rule out sectoral difference in represen- 
tativeness from firms' entry into and exit from the database, which not necessarily reflect firms' entry and exit decisions, and the influence of the global financial crisis, we restrict to the sample of continuing firms for the before-crisis period. We then use the resulting sample to first aggregate over time for each firm to construct firm-level dependence, and then take median value for each industry to arrive at the industry-level measure for external finance dependence. An industry is defined as an SIC two-digit sector in constructing both measures, consistent with industry classifications in our regression analysis.

\section{A.3 National Accounts Data}

Our aggregate data on national accounts (Figure 1 and Table 1) is extracted from the World Economic Outlook Database from the IMF. The saving and investment data by sectoral (Table 3) is collected from flows-of-funds table of the sample countries. A detailed description is provided in the supplementary material. 